Journal of Hospitality and Tourism Management

http://journals.cambridge.org/JHT

Additional services for Journal of Hospitality and Tourism Management:

Email alerts: Click here

Subscriptions: $\underline{\text { Click here }}$

Commercial reprints: Click here

Terms of use : $\underline{\text { Click here }}$

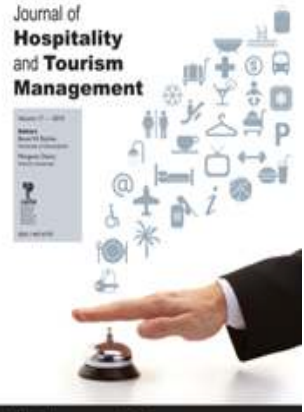

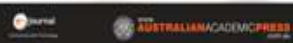

\title{
Lived Experiences of Early Career Researchers: Learning About and Doing Grounded Theory
}

Gayle Jennings, Sandra Kensbock, Olga Junek, Kylie Radel and Ulrike Kachel

Journal of Hospitality and Tourism Management / Volume 17 / Issue 01 / December 2010, pp 21 - 33

DOI: 10.1375/jhtm.17.1.21, Published online: 23 February 2012

Link to this article: http://journals.cambridge.org/abstract S1447677000000607

How to cite this article:

Gayle Jennings, Sandra Kensbock, Olga Junek, Kylie Radel and Ulrike Kachel (2010). Lived Experiences of Early Career Researchers: Learning About and Doing Grounded Theory. Journal of Hospitality and Tourism Management, 17, pp 21-33 doi:10.1375/jhtm.17.1.21

Request Permissions : $\underline{\text { Click here }}$ 


\section{Lived Experiences of Early Career Researchers: Learning About and Doing Grounded Theory}

\author{
Gayle Jennings and \\ Sandra Kensbock \\ Griffith University, Australia \\ Olga Junek \\ Victoria University, Australia
}

Kylie Radel

CQUniversity Rockhampton, Australia

\section{Ulrike Kachel}

Griffith University, Australia

\begin{abstract}
In this phenomenologically influenced study, three early career researchers share their lived experiences of engaging with grounded theory as either a 'methodology' or 'method' in their respective research projects. The three lived experiences were interpreted using a constructivist grounded theory approach. The study provides insights into their experiences associated with 'learning about' and 'doing' grounded theory. Based on these three early career researchers' experiences, learning to be a grounded theory researcher is constituted of three inter-connected processes: learning about and doing grounded theory (and qualitative research); researchers as socially situated and embodied, corporeal beings; and experiences of grounded theory learning contexts and curricula. Additionally, learning about and doing grounded theory is a multifaceted social experience involving knowledge building, meaning making, skill development, reflexivity, axiology, conducive learning conditions, communities of practice principles as well as influences from researchers' affective domains.
\end{abstract}

Keywords: early career researchers, lived experiences, grounded theory
For early career researchers and nascent qualitative researchers, depending on their background, grounded theory can be perplexing because like many current qualitative research approaches; grounded theory is associated with emergent research designs and the tailorising of methods to local research contexts and participants. In addition, as such researchers immerse themselves in grounded theory literature, the contested nature of grounded theory becomes evident. The literature abounds with different opinions and approaches to grounded theory (Jennings \& Junek, 2007). Subsequently, researchers can be left wondering whose opinion and which approach to follow? When drawing on the seminal writers, should they follow Glaser and Strauss (1967), or Glaser (1992) or Strauss and Corbin (1990, 1998), Corbin and Strauss (2008) or Charmaz (2003, 2006)? And of the variety of models within tourism and hospitality literature (refer to Table 1), which should they follow there?

Concomitantly, early career and nascent qualitative researchers have to contend with the problematic space of learning attendant language. And then too, there are ontological, epistemological, methodological and axiolog-

\section{Correspondence}

Gayle Jennings, Associate Professor in Tourism Management, Griffith Business School, Gold Coast campus, Griffith University, Gold Coast QLD 4222.

E-mail: g.jennings@griffith.edu.au ical perspectives and positions associated with the varying styles of grounded theory. Consequently, for early career and nascent qualitative researchers, a plethora of questions, reflections and decision-making shapes their initial and continuing lived experiences of engaging with grounded theory. But what is the nature of those lived experiences? This is the phenomenological question that this paper addresses. And here we use the term 'phenomenology' in the sociological and education-based use of the term rather than in a philosophical sense. In particular, we draw on hermeneutic phenomenology, that is, 'that domain of experience that occurs in our direct acquaintance with things, as opposed to what occurs secondarily through abstract reflection' (Barnacle, 2001). In addressing our question, the paper aims to provide insights into 'the nature or essence of ... experience[s] of learning' (van Manen, 1990, p. 10) about and doing grounded theory by three early career researchers.

\section{Lived Experiences of Early Career Researchers: Study Significance}

The question, 'What is the nature or essence of the experience of learning about and doing grounded theory?' arose during a collective qualitative research dialogue session, which included the authors of this article. In this session, it became evident to us that a number of session members were experiencing or had experienced similar as well as different lived experiences related to engaging with grounded theory. Others in the session suggested as they had not yet 
Table 1

A Snapshot of Grounded Theory Usage in Tourism and Hospitality Studies: Potential Models

\begin{tabular}{|c|c|c|}
\hline Year & Author(s) & Title of work \\
\hline & & Tourism Studies examples \\
\hline 1995 & Riley & Prestige worthy tourism behaviour \\
\hline 1996 & Riley & $\begin{array}{l}\text { Revealing socially constructed knowledge through quasi-structured interviews and grounded theory } \\
\text { analysis. }\end{array}$ \\
\hline 1997 & Connell \& Lowe & $\begin{array}{l}\text { Generating grounded theory from qualitative data: the application of inductive methods in tourism } \\
\text { and hospitality management research }\end{array}$ \\
\hline 1997 & Jennings & The travel experience of cruisers \\
\hline 1999 & Jennings & Voyages from the centre to the margin: An ethnography of long term ocean cruisers. \\
\hline 1999 & Goulding & Heritage, nostalgia, and the "grey" consumer \\
\hline 2000 & Goulding & $\begin{array}{l}\text { The commodification of the past, postmodern pastiche, and the search for authentic experiences } \\
\text { at contemporary attractions }\end{array}$ \\
\hline 2001 & Hillman & Backpackers travelling in Australia \\
\hline 2002 & Coleman \& Crang & Being-on holiday: tourist dwelling, bodies and place \\
\hline 2002 & Johns \& Gyimothy & Mythologies of a theme park: an icon of modern family life \\
\hline 2003 & Hobson & The case for more exploratory and grounded tourism research. \\
\hline 2003 & Mehmetoglu \& Olsen & $\begin{array}{l}\text { Talking authenticity: What kind of experiences do solitary travellers[sic] in the Norwegian Lofoten } \\
\text { Islands regard as authenticity? }\end{array}$ \\
\hline 2004 & Junek & $\begin{array}{l}\text { A qualitative inquiry into leisure and travel patterns of international students: Part } 1 \text { - Background } \\
\text { and methodology }\end{array}$ \\
\hline 2004 & Lim & Grounded theory approach to travel behaviour research \\
\hline 2004 & Woodside, McDonald \& Burford & Grounded theory of leisure travel \\
\hline 2004 & Daengbuppha, Hemmington \& Wilkes & $\begin{array}{l}\text { Using grounded theory approach: Theoretical and practical issues in modelling heritage } \\
\text { visitor experience }\end{array}$ \\
\hline 2005 & Jennings & Caught in the irons: one of the lived experiences of long-term ocean cruising women \\
\hline 2005 & Hardy & Using grounded theory to explore stakeholder perceptions of tourism \\
\hline 2005 & Decrop \& Snelders & A grounded typology of vacation decision-making \\
\hline 2006 & Cunningham & Social valuing for Ogasawara as a place and space among ethnic host \\
\hline 2007 & Kim \& Jamal & Tourist quest for existential authenticity \\
\hline 2007 & Santos \& Buzinde & Politics of identity and space: Representational dynamics \\
\hline 2008 & Stevenson, Airey \& Miller & Tourism policy making: The policymakers' perspective \\
\hline \multirow[t]{2}{*}{2009} & Lawton \& Weaver & Travel agency threats and opportunities: The perspective of successful owners \\
\hline & & Hospitality examples \\
\hline 1997 & Connell & International hotel franchise relationships - UK franchisee perspectives \\
\hline 1998 & Mattsson \& den Haring & Communication dynamics in the service encounter \\
\hline 2003 & Kwortnik & Depth interviews and qualitative analysis \\
\hline 2003 & Walsh & Qualitative research: Advancing the science and practice of hospitality \\
\hline 2005 & Hansen, Jensen \& Gustafsson & The meal experience of a la carte restaurant customers \\
\hline 2005 & Lynch & Sociological Impressionism in a hospitality context \\
\hline 2005 & Presbury, Fitzgerald \& Chapman & Impediments to improvements in service quality in luxury hotels \\
\hline 2006 & Mehmetoglu \& Altinay & Examination of grounded theory analysis with an application to hospitality research \\
\hline 2007 & Jensen \& Hansen & Consumer values among restaurant customers \\
\hline 2007 & Kubacki, Skinner, Parfitt \& Moss & Comparing nightclub customers' preferences in existing and emerging markets \\
\hline 2007 & Testa & A deeper look at national culture and leadership in the hospitality industry \\
\hline 2008 & Bender, Partlow \& Roth & An examination of strategic drivers impacting US multinational lodging corporations \\
\hline 2009 & Kim, Eves \& Scarles & Building a model of local food consumption on trips and holidays: A grounded theory approach \\
\hline
\end{tabular}

engaged with grounded theory that it would be good to later hear and/or read (again) such lived experiences. This they suggested would help them with any future excursions they undertook with grounded theory as they would have a more informed and corporeal understanding of the nature of the lived experience. In sharing such experiences and by enlarging our audience, we realised that we could also contribute to the 'meaning making' (Schwandt, 2000) experiences of other researchers and educators (Jennings, Scantlebury and Wolfe, 2009) as they engaged with grounded theory.

Elsewhere, it has been noted that the lived experiences of research students is an under-theorised area (Jennings et al., 2009). Consequently, this paper contributes to the growing body of literature that gives voice and theorises research students' experiences. Relatedly, the article makes a phenomenological 'theoretical' contribution by providing 'a deeper understanding of the nature or meaning of our everyday experiences' (van Manen, 1990, p. 9). In this article, the focus is on understanding the 
lived experiences of three research students as early career and nascent qualitative researchers while engaging in grounded theory. Specifically, the paper does this by extracting the 'essence' (van Manen, 1990, p. 9) of their experiences of learning about and doing grounded theory. In addition to these theoretical contributions, the article makes two praxis contributions: the modelling of grounded 'theory into practice'; and a demonstration of interpretive processes associated with grounded theory. Another such modelling is found in the writing of Soklaridis (2009), who provides an overview of qualitative research and grounded theory processes used for her health sciences doctoral thesis.

\section{Methodology and Methods}

Research of lived experiences is situated in hermeneutic phenomenology; that is, the study of 'the nature or meaning of everyday experiences' (van Manen, 1990, p. 9). Why did we choose to focus on lived experiences? We did so because the study of lived experiences enabled us to essentialise those lived experiences and to share these through textual representation. The text thereby provides 'a reflexive re-living and a reflective appropriation of something meaningful' (Van Manen, 1990, p. 36). Lived experiences differ from post/positivistic traditions. In the words of Dilthey (1985, p. 223):

A lived experience does not confront me as something perceived or represented; it is not given to me, but the reality of lived experiences is there-for-me because I have a reflexive awareness of it, because I possess it immediately as belonging to me in some sense. Only in thought does it become objective.

In this study, we were informed by van Manen's (1990) seminal work on lived experience, which was derived from Husserl's lebenswelt 'lifeworld' concept (van Manen, 1990, p. 7). Lifeworld incorporates both 'everyday, intuitive life' as well as recognition of the 'multiplicity of particular worlds' (Barnacle, 2001). We chose van Manen's work to inform our research design as his work was education focused, with a particular emphasis on 'Bildung [(education)] or paideia - the curriculum of being and becoming' (van Manen, 1990, p. 7). The synergies between van Manen's and our lived experience work lie in their educative foci.

In saying this, we were cognisant in our research design phase of the critiques of van Manen's position as being too practice rather than theory based, see for example, Barnacle (2001). We were also cognisant of the more recently promoted participatory paradigm, which valorises practical and experiential knowledge (see Jennings, 2009; Jennings, 2010). In resolving our position with regard to these differing positions, we have chosen to integrate van Manen's lived experience with a constructivist grounded theory method of interpretation. This positions our study as 'a co-constructed narrative' (Gergen \& Gergen, 2000, p. 1042) and situates it in what has been described as the seventh moment - 'the methodologically contested present' of qualitative research (Denzin \& Lincoln, 2005, p. 20). Although Denzin and Lincoln (2005, p. 20) frame this period as $2000-2004$, we argue that that moment is still evident within tourism and hospitality studies. See related writings regarding tourism studies having taken a critical turn in research approaches and foci (Tribe, 2007) and Ateljevic, Morgan \& Pritchard (2007).

\section{Lived Experiences of Early Career Researchers: Paper Style and Structure}

The article uses a narrative style written primarily in first person voice. Structurally, it does not adopt the usual scientific report style; instead it integrates three 'structurings' suggested by van Manen (1990, pp. 168-171). Those structurings are 'exemplificatively', 'thematically', and 'analytically'. Exemplificatively structuring allowed us to organise the phenomenological writing by providing three examples of differing modalities, in our case, of learning about and doing grounded theory. Thematically structuring enabled us to make visible the essential themes arising out of the lived experiences; also assisted by grounded theory. Here the challenge for us, as van Manen cautioned, was 'how to treat each of the themes systematically, even though one theme always implicates the meaning dimensions of other themes' (1990, p. 168).

Our thematic discussion follows the presentation of the exemplified lived experiences. In considering the essential themes of the lived experiences, we simultaneously address 'the insights of others' related to the same 'phenomenon' (van Manen, 1990, p. 75). And it is here that we refer to related literature reviews. This approach mirrors other grounded theory approaches wherein the literature review is integrated in the latter part of papers (see Glaser, 1992; Jennings, 2010).

The analytical structuring of our writing appears as we present our grounded theory of the lived experiences of learning about and doing grounded theory. In this section, we reconstruct the three lived experiences based on their themes in order to enable the lived experience 'phenomenon' to 'be meaningfully understood' (van Manen, 1990, p. 170) as we theorise the early career researchers' lived experiences.

\section{Lived Experiences of Early Career Researchers' Engagement With Grounded Theory}

As already intimated, the specific storying of this paper is based on the lived experiences of three of the authors and their early career research experiences of engaging in grounded theory. Their lived experiences were generated in the course of pursuing their respective $\mathrm{PhD}$ studies. Two of the students used grounded theory as both 'methodology' and 'method' and one used grounded theory as the 'method'/strategy. Methodology herein means 'a methodolog[ical tradition], a way of thinking about and studying realit[ies]' (Strauss \& Corbin, 1998, p. 4); while a method means 'a strategy for research and a way of [interpreting empirical materials or] analysing data' (Jennings \& Junek, 2007, p. 199). 


\section{Exemplificatively Structuring: Lived Experiences of Early Career Researchers' Engagement With Grounded Theory}

The article now presents the three lived experiences of learning about and using grounded theory. These include grounded theory used in a social constructionist interpretive study of entrepreneurs; in association with Indigenous epistemologies by a non-Indigenist researcher, as well as in an intercultural research application.

In the lived experiences, each of the researchers carries within themselves specific positionalities and research foci that influence their interpretation and design/approach to grounded theory. Subsequently, each of the lived experiences narrated will introduce the researcher (positionality), their research purpose, rationale of use of grounded theory (incorporating paradigmatic influences - ontology, epistemology, methodology and axiology), reflexive considerations/thoughts and grounded theory that emerged.

\section{Lived Experience 1}

The purpose of my research was to investigate tourism entrepreneurs' understandings of sustainable tourism. As my research was exploratory I was not using traditional $a$ priori assumptions of an upfront hypothesis. Therefore, I needed an analysis method, and immersed myself in reading qualitative research textbooks. There appeared many differing approaches to qualitative research and I found frequent mention of 'grounded theory' as a research method of generating theory that is grounded in participants' voices, actions and experiences. As a nascent researcher, I felt a need to know 'how to' and grounded theory appeared to offer steps in an analytical process that I could understand and follow.

I was very fortunate to find a supportive supervisor with extensive experience in using grounded theory. Under my supervisor's direction, I read Glaser and Strauss's (1967) seminal work, and subsequent Glaser (1978, 1992, 1994, 1998, 2001, 2007), and Strauss and Corbin $(1990,1998)$ clarifications. On reading Glaser's (1992) denunciation of Strauss and Corbin, I was able to more critically evaluate grounded theory methodology. Further reading exposed me to Charmaz's (1994, 2000, 2005) perceptions of positivist, objectivist assumptions in both Glaser's, and Strauss and Corbin's writings. I found this a difficult and confusing stage in my research as my comprehension of research foundations was oscillating between dualistic and non-dualistic ontologies, as well as trying to understand what grounded theory involved. I found I aligned with Charmaz's (2000) social constructionist assumption of multiple realities that is predicated on an epistemology of co-creation of understanding. Social constructionism provided for a conception of theory 'generation' with assumptions of my involvement in the interaction, interviewing and analysis processes. It was in this way that my interpretation and use of grounded theory diverged from the Glaserian stance, however, the methods I employed followed the essential cornerstones of grounded theory's 'explicitly formulated methodology' (Glaser, 1994, p. 1).

I used thematic areas to form open-ended questions in my initial semi-structured interviews and let the conversation range to participant's concerns and issues relevant to their understanding of sustainable tourism. I transcribed recorded interviews verbatim as this allowed accurate empirical material. I found Glaser and Strauss's (1967) methodology as well as Glaser's (1978) Theoretical Sensitivity a solid foundation to approach my analysis. The initial open coding (substantive) took a word and line-byline analysis, using gerund descriptors. I found this an amazing experience as these initial open codes came quickly (as promised by Glaser; see Figure 1).

However, the next step of constant comparison of codes to find similarities, differences and dimensions quickly became a 'methodical mess'. Initially my memos were short, and having unique line numbers in interview transcriptions meant I was able to maintain references to empirical material for grounding. These memos became longer and more numerous and I felt I was swamped, unable to generate any sense in what I had coded, and that I was repeating myself in my memos. These difficult and confused days were quickly ended when I cut up my memos and sorted them. To my amazement, there were clear categories and my human instrument was working overtime in an iterative, inductive and deductive examination of relationships between as well as dimensions of each category. Theoretical sampling allowed selection of information rich participants, as well as a selective method for development of questions for the next interview based on concepts that were emerging from analysis of empirical material. As a grounded theory researcher, my position was to keep an open mind as to the array of possible theory that may offer the best and most plausible explanation of tourism entrepreneurs' understandings of sustainable tourism. My search for relevant literature involved several 'goose-chases' that were time consuming. However, I found this broad reading improved my ability to use ideas analytically through the process of emergent fit. Literature I examined that was not relevant to my analysis still resulted in some intellectual development on my part. Sensitising me to the analytic situation was my acquired academic knowledge, and also my life experiences as a businesswoman and a mother.

Following my supervisor's recommendation, I maintained a reflexive journal throughout the research process.

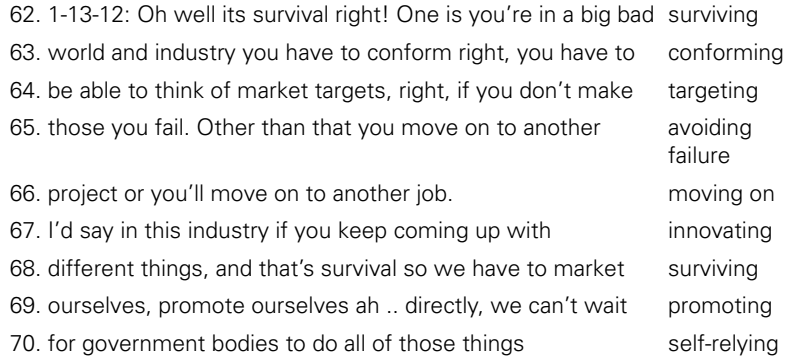

69. ourselves, promote ourselves ah .. directly, we can't wait 70. for government bodies to do all of those things

Figure 1

Example of my initial open coding. 
Daily entries allowed added insights regarding my research experience, such as gender issues as a woman interviewing men, and axiological issues related to my approach to research. These entries enabled self-questioning, as while I felt sure that categories I had generated were grounded in empirical material, I questioned my analysis. Was I imposing action on empirical material? Was another (or better) analysis possible? I also realised that I would have difficulty generating anything other than the basic social process I 'saw.' An ontological and epistemological approach of multiple meanings and realities accepts that others may have different views. While accepting differing interpretations are possible grounded theory requires saturation of categories, so this works to establish consensus regarding my interpretation of concepts. Also, participants' confirmation when I explained my findings in a 'member-checking' process was thrilling, as I felt I had obtained 'fit' in the substantive area. I found my reflexive journal an excellent aide to monitor my progress, and these journal entries were reviewed throughout my analysis and write-up of my discussion, and also provided a record of my anguish and triumphs.

As a nascent researcher the grounded theory analysis tools developed by Glaser and Strauss provide a sound structure to approach analysis of empirical material. My social constructionist version of grounded theory provided a methodology that revealed participants' lived experiences and understandings that was the purpose of my research.

\section{Lived Experience 2}

As a university lecturer and previously a teacher, I have always been interested in international students studying in Australia, and in particular how they spend their time - their study and work time as well as their leisure or nonstudying and nonworking time. My interest was not only in what they do or don't do in their leisure time, but also what drives or constrains them to undertake - or conversely - not undertake certain leisure activities. I sought to discover the reasons and motivations that lie behind decisions made regarding their leisure activities and I also hoped to recognise some of the challenges international students face during their time away from their home country, not only in their studies but also in the totality of their life. I wanted to comprehend the complexity of these students' decisions concerning their leisure time, whether that time was spent differently from that in their home country and I also wanted to understand their travel patterns while studying in Australia. As the students in my research were tourism, hospitality and events students I saw the research as a great opportunity to investigate whether they in fact, 'lived what they were studying'.

My first thoughts and ideas about the paradigm of my research were not about a purely qualitative but rather a mixed method approach. It was only when I began discussing this approach with my supervisor that I began to question the quantitative methodology I had originally contemplated as being suitable for my research. Slowly I began to realise that the in-depth knowledge I was seeking would be much better obtained through a purely qualitative approach. Once I realised that it was the qualitative methodology that appealed to me, especially the interpretive, constructivist paradigm, I also began to look more closely at grounded theory, having discussed this possibility with my supervisor. After reading the seminal works of Glaser and Strauss (1967) but also other researchers who had adapted a slightly different approach to grounded theory such as Charmaz (2005), I began to see how this methodology would allow me the freedom and flexibility of data analysis, yet at the same time give me a certain structure in the methods used. I also liked the fact that I would be able to get close to the data collected and would be able to construct and reconstruct this material together with my research participants, notwithstanding my position as their lecturer, something which has been addressed from the beginning of this research in the process of critical self-awareness, self-reflexivity and self-disclosure.

Thus, I felt, the interpretive, constructivist paradigm and the use of grounded theory, both as a methodology and in the methods used, would allow me to gain insight and understanding of students' leisure and travel patterns and the identification and subsequent interpretation of the students' multiple realities and their 'lived experiences' in leisure and travel.

Collection of empirical material through the methods of focus groups and semistructured in-depth interviews presented me with a wealth of material which I continuously listened to, read, coded, made memos and generally tried to make sense of. This process of constant comparison, of going back over material, comparing it to material emerging from other research participants and also to the literature, is central to the development and refining of categories which may then lead to a theoretical framework or theory. So it was also for me that through the students' stories I began to see the emergence of forces that shaped the students' experience and participation in leisure activities. Asking participants about their whole leisure and travel experiences rather than merely what motivates them or what they do in their leisure time, other issues and themes emerged which allowed me to see leisure as part of their whole life experience while in Australia. The depth and understanding of the research problem that I had hoped for was emerging through the constant analysis of the material as I was still interviewing other students and getting new material. There was no clearly defined beginning and end to the research process, it was continuous and thus allowed me to question new participants about aspects that had already emerged through completed interviews.

One of the questions that researchers using grounded theory are faced with is whether they will know when the theory starts to emerge from the material collected and analysed. I too, had similar concerns as to how I would know that a theory was in fact emerging. Would it be obvious, would it be like a light bulb that suddenly turns on or would it be more laborious and uncertain? For me, there came a realisation through the process of categorising and construction/reconstruction of four central themes and concepts that these are at the core of the beginnings 
of an emergent theory of 'being-ness and connectivity'. The process is by no means at an end, what remains now is further analysis of the interview material as well as of the literature, member checking and further refinement and development of the theory. The theory that will then emerge will have been fully grounded in the empirical material constructed and reconstructed mutually with me as principal researcher and international students as fellow researchers.

\section{Lived Experience 3}

My study sought to understand the practices and processes used by Indigenous tourism enterprise staff, as they mediate between western and Indigenous spaces in the Queensland tourism context. Particularly, the focus for the study centred on the mediation processes that served to enable an Indigenous tourism enterprise to be 'successful' from both Indigenous and western perspectives. In order to gain an understanding of these processes, the study applied a constructivist-interpretive paradigm (Charmaz, 2000; Denzin \& Lincoln, 2000; Guba \& Lincoln, 1994; Lincoln \& Guba, 2000) informed by Indigenous research protocols (Australian Institute of Aboriginal and Torres Strait Islander Studies, AIATSIS, 2000) and methodological standpoints. Drawing on these traditions, the research developed a grounded theory of key success factors for an Indigenous enterprise in the Queensland tourism industry as constructed through the voices and perspectives (Hertz, 1997; Lincoln \& Guba, 2000) of staff.

\section{Contexts of the Research}

Past research into Indigenous issues and peoples both in Australia and globally has been subject to mismanagement, controversy and disrespect (Dodson, 2000; Dodson \& Smith, 2003; Ivanitz, 1999; Radel, 2005; Scheurich, 1997; Smith, 1999; Stanfield II, 1994). Such research has enabled the creation of an 'Indigenous reality' that has little or '... no Indigenous input, in a language that is nonIndigenous by and for a non-Indigenous audience' (Foley, 2003. p. 44). Until recently in the Australian context, research 'on Aboriginal people ... [and] on Aboriginal lands was done without the permission, consultation, or involvement of Aboriginal people' (Martin, 2003, p. 203). Further, research into Indigenous enterprises has been proposed, implemented and acted upon without Indigenous enterprise operator input or consultation (Arthur, 1999; Martin, 2003). This often arbitrary gathering of information that has little relevance to, and provides a poor reflection of the 'reality' of the environments and lived experiences of the peoples it purports to explain, clearly demonstrates the need for Indigenous involvement and consultation in research and the ongoing development of Indigenous and Indigenist research perspectives (Bourke, 1995; Foley, 2003; Nakata, 1998; Rigney, 1996, 2001a; Smith, 1999).

With these contextual understandings of research with Indigenous peoples in mind, my positionality in the study as a non-Indigenous researcher had to be both recognised explicitly and reflexively discussed. The research is not value neutral; it is person centred and both the researcher and the informants have life stories and lived experiences which inevitably impacted on the study (Giddens, 1982; Martin, 2003; Smith, 1999; Vidich \& Lyman, 2000). The constructivist-interpretive paradigm provided a space to voice (Hertz, 1997) those realities through allowing the recognition of the personal construction of knowledge, identity, social roles and (re)actions (Berger \& Luckman, 1966; Dilthey, 1989; Lincoln \& Guba, 2000). Fundamentally the axiology of constructivism is that of 'transactional knowing' (Lincoln \& Guba, 2000, p. 172) and this '... assumes the relativism of multiple social realities, recognises the mutual creation of knowledge by the viewer and the viewed, and aims toward interpretive understanding of subjects' meanings' (Charmaz, 2000, p. 510). The contribution of the constructivist-interpretative paradigm to Indigenous methodology development and application is the progression of a culturally sensitive approach to research which demonstrates '.. flexibility [and] a willingness to allow for the emergent' (Oates, 2003, np).

The constructivist-interpretative paradigm seems appropriate and commensurate with the needs and concerns as laid out by Indigenous research methodology proponents (see Brady, 1992, 2001; Foley, 2000, 2003; Martin, 2003; Moreton-Robinson, 2003; Nakata, 1998; Oates, 2003; Rigney, 1999, 2001b, 2003; Smith, 1999). While essentially westernised, the paradigm provided epistemological, ontological and axiological perspectives to focus the research and myself as researcher on the interactions, fundamental cultural positions and ideologies of the informants while allowing me to recognise myself in the setting and to reflexively examine my own positionality.

Reflexivity was used extensively to establish an intensive "scrutiny of "what I know" and "how I know it" (Hertz, 1997, p. viii), which resonated with the values and ethics guidelines of the National Health and Medical Research Council (NHMRC, 2003, p. 3) as well as being apposite with Indigenous methodological standpoints.

\section{Doing Grounded Theory}

My approach to doing grounded theory was particularly informed by Charmaz (1990, 2000, 2002, 2003, 2006). However, I collected empirical material through conversations with research partners rather than using interviews or focus groups with participants. I did not tape-record any of these conversations as the staff were particularly concerned with any means of identifying individuals that may come with such audio or video transcripts. I reflexively recorded my thoughts and reactions post the sessions and I also relied on observation of staff interactions to build a holistic picture of the practices and processes of the enterprise. I used reflexivity extensively to question my understandings and also to examine the content and contexts of the many conversations with partners.

My grounded theory approach provided a space to articulate an emergent theory of success factors framed through the lived experiences of the individuals involved in the Indigenous business processes '... grounded through active interplay with the data [sic]' (Strauss \& Corbin, 1998, p. 6). Through constant comparison, I 
developed a set of categories based on microanalysis of the empirical material. Developing a systematic process to interpret my understandings of meanings (Silverman, 1993; Strauss \& Corbin, 1998), I used a two-column table containing the transcripts down the left and memos down the right and subdivided by paragraphs rather than line-by-line due to the volume of material that was gathered. My constant comparison process also not only compared empirical material to empirical material, but continuously returned to the staff (as research partners) for verification and re-storying; to ensure the emerging themes reflected the daily lived realities.

The research process, empirical materials developed, myself as researcher, my research partners, and my interpretations were integrated and theory evolved from this interplay (Strauss \& Corbin, 1994).

The final, and for me the most challenging, process of doing grounded theory is writing the theory. My process has been to draw the theory - immersing myself in the transcripts, moving from memos to categories through sorting the memos and further refining my interpretations - continuing to draw and redraw the spaces and boundaries that were unfolding. Many times my supervisors would demand more words to explain the pictures. I sorted chunks of the transcripts under each category 'heading' and wrote the narrative of the grounded theory around these chunks. This then re-informed the development of my theoretical diagram - through many, many drafts. The process is a crystallisation - a multi-faceted integration of narrative and diagram - telling the story in both words and pictures. The grounded theory approach (underpinned by a constructivist-interpretative paradigm and informed by Indigenous research methodologies), supports an interpretive space allowing for mediation between informants' meanings and researcher's understandings which ensures the emergent theory will 'fit' the Indigenous enterprise contexts and 'work' (Glaser \& Strauss, 1967, p. 3) for the Indigenous staff.

\section{Thematically Structuring: Lived Experiences of Early Career Researchers' Engagement With Grounded Theory}

Having presented the lived experience narratives, we now share our grounded theory interpretation of the three lived experiences of learning about and doing grounded theory. The grounded theory approach we used in this process was based on Charmaz's (2003, 2006) perspectives. We chose her approach because of synergy between our use of lived experiences and her constructivist view, which 'recognises that the viewer creates the empirical material and the ensuing analysis through interaction with the viewed' (Charmaz, 2000, p. 523).

We also recognised from a phenomenological perspective that such an approach to grounded theory enabled us to move from the everyday world of practical experience to the consideration of the multiplicity of worlds and others' experiences. In doing this, we aimed to address Barnacle's (2001) critique of van Manen's work. A critique that Charmaz appears to address in saying:
... we are part of the world we study and the data we collect. We construct our grounded theories through our past and present involvements and interactions with people, perspectives, and the research practices. (2006, p. 10).

The following explains the processes we used to interpret the three lived experiences. The lived experience texts were individually and collectively interpreted. Table 2 provides snapshots of some of the first codes that were identified in regard to using grounded theory based on what appeared to be an immersion stage experienced by the researchers as they learnt about and commenced doing grounded theory. The snapshot contains codes related to processes where the three researchers were learning about and doing grounded theory. This doing was initially associated with their approximations which could be located along a continuum of grounded theory approaches as well as with practice. The role of reflexivity also was noted as apparent and subsequently coded.

The earlier codes noted in Table 2 as well as others not presented here, due to space limitations, were framed within themes and recorded on post-it notes. After successive recoding and (re)interpreting the codes and their associated meanings the final essential themes were distilled. These themes were organised, not surprisingly given the nature of the phenomenological question, into three frames: experiences related to learning about and doing grounded theory, which were overlayed by experiences of the researchers as embodied and corporeal beings; and the experience of grounded theory learning contexts and curricula. Subsumed within these three areas are linkages to van Manen's reference to the curriculum of 'being and becoming' (van Manen, 1990, p. 7). Such a curriculum of being and becoming also had linkages to Wenger's (1998) principles of learning associated with communities of practice.

Communities of practice exhibit four characteristics (and related processes): community (belonging), identity (becoming), meaning (experiences), and practice (doing). Additionally, there are three elements to communities of practice: 'domain of knowledge', 'community', and 'practice' (Snyder et al. 2004). Each of the early career researchers was involved in a qualitative research dialogue collective that was framed around Wenger's communities of practice principles. The collective had a domain of knowledge predicated on qualitative research. The community was constituted of qualitative researchers ranging from early career and nascent researchers to established career researchers. The early career researchers were able to practice grounded theory and were coached by other members of the collective. Additionally, their supervisors were also members of this collective.

\section{Thematically Structuring: Learning About and Doing Grounded Theory}

The subthemes of the essential theme of learning about and doing grounded theory included experiences in learning about and doing qualitative research processes, and meaning making experiences associated specifically with grounded theory. The experiences in learning about and doing qualitative research processes incorporated building 


\begin{tabular}{|c|c|c|}
\hline $\begin{array}{l}\text { Research focus, research design decision-making } \\
\text { processes - grounded theory - immersion }\end{array}$ & Practice & Reflexivity \\
\hline Immersed myself in reading qualitative research textbooks. & $\begin{array}{l}\text { Theoretical sensitivity a solid foundation to } \\
\text { approach my analysis. }\end{array}$ & $\begin{array}{l}\text { Began to question the quantitative methodology } \\
\text { I had originally contemplated. }\end{array}$ \\
\hline Read Glaser and Strauss' seminal work. & $\begin{array}{l}\text { Word and line-by-line analysis using } \\
\text { gerund descriptors. }\end{array}$ & $\begin{array}{l}\text { Maintained a reflexive journal throughout the } \\
\text { research process. }\end{array}$ \\
\hline Glaser's denunciation of Strauss and Corbin. & Open codes came quickly. & $\begin{array}{l}\text { Added insights regarding my research experience. } \\
\text { gender issues ... axiological issues. }\end{array}$ \\
\hline $\begin{array}{l}\text { I was able to more critically evaluate grounded theory } \\
\text { methodology. }\end{array}$ & $\begin{array}{l}\text { Constant comparison ... became a } \\
\text { methodical mess. }\end{array}$ & Entries enabled self-questioning. \\
\hline $\begin{array}{l}\text { The in depth knowledge I was seeking would be much } \\
\text { better obtained through a purely qualitative approach. }\end{array}$ & $\begin{array}{l}\text { Several 'goose-chases' that were } \\
\text { time consuming. }\end{array}$ & $\begin{array}{l}\text { Found this a difficult and confusing stage in my } \\
\text { research. }\end{array}$ \\
\hline $\begin{array}{l}\text { I liked the fact that I would be able to get close to the } \\
\text { data collected. }\end{array}$ & That I was repeating myself in my memos. & $\begin{array}{l}\text { Process of critical self-awareness, self-reflexivity and } \\
\text { self-disclosure. }\end{array}$ \\
\hline $\begin{array}{l}\text { Began to see how this methodology would allow me } \\
\text { the freedom and flexibility of data analysis. }\end{array}$ & I cut up my memos and sorted them. & $\begin{array}{l}\text { Use of reflexivity to establish an intensive 'scrutiny } \\
\text { of "what I know" and "how I know it". }\end{array}$ \\
\hline Found frequent mentioning of 'grounded theory'. & $\begin{array}{l}\text { This process of constant comparison .... } \\
\text { is central to the development and refining of } \\
\text { categories. }\end{array}$ & Was another (or better) analysis possible? \\
\hline I aligned with Charmaz' social constructionist assumptions. & $\begin{array}{l}\text { Through the students' stories I began to see } \\
\text { the emergence of forces that shaped the } \\
\text { students' experience and participation in } \\
\text { leisure activities. }\end{array}$ & $\begin{array}{l}\text { Questions of whether they will know when the } \\
\text { theory starts to emerge from the material collected } \\
\text { and analysed. }\end{array}$ \\
\hline Progression of a culturally sensitive approach to research. & $\begin{array}{l}\text { Other issues and themes emerged } \\
\text { that allowed me to see leisure as part of } \\
\text { their whole life experience. }\end{array}$ & Was I imposing action on empirical material? \\
\hline $\begin{array}{l}\text { Appropriate and commensurate with the needs and } \\
\text { concerns as laid out by Indigenous research methodology } \\
\text { proponents. }\end{array}$ & Active interplay with the data. & $\begin{array}{l}\text { Developing a systematic process to interpret my } \\
\text { understandings of meanings. }\end{array}$ \\
\hline $\begin{array}{l}\text { Multiple realities that are predicated on an epistemology } \\
\text { of co-creation of understanding. }\end{array}$ & $\begin{array}{l}\text { Developed a set of categories based on } \\
\text { microanalysis of the empirical material }\end{array}$ & $\begin{array}{l}\text { Reflexively recorded my thoughts and reactions post } \\
\text { the sessions. }\end{array}$ \\
\hline $\begin{array}{l}\text { Space to articulate an emergent theory of success factors } \\
\text { framed through lived experiences. }\end{array}$ & $\begin{array}{l}\text { Constant comparison process not only } \\
\text { compared empirical material to empirical } \\
\text { material, but continuously returned to the } \\
\text { research partners for verification and re-storying. }\end{array}$ & $\begin{array}{l}\text { The research process, empirical materials developed, } \\
\text { myself as researcher, my research partners and my } \\
\text { interpretations were integrated and theory evolved } \\
\text { from this interplay. }\end{array}$ \\
\hline
\end{tabular}

knowledge about paradigms, sampling, coding, (re)construction/(re)interpretation, locating and identifying relevant information sources. Meaning making experiences associated with grounded theory focused on paradigmatic and literature influences, grounded theory selection, understanding of emergent research designs and theory building, and interpretive processes and skills. Evident in these themes, as noted by van Manen (1990, p. 168) are the influences of one theme upon the 'meaning dimensions of other themes'. As van Manen commented, we found that the interconnectivity of essential themes and sub-themes in the lived experiences were unable to be systematically disassociated. When juxtaposed against extant literature, the experiences of these three early career researchers resonated with the writings of Hobson, 2003; Jennings, 1999; Jennings and Junek, 2007; Kensbock, 2007; Gurung, 2008; and Soklaridis, 2009.

\section{Thematically Structuring: Experiences of the Researchers as Embodied and Corporeal Beings}

Strongly resonating within the researchers' lived experiences was their embodied and corporeal beingness. For as researchers, they were socially situated and contextualised human beings who also experienced personal and social experiences of learning about and doing grounded theory. They were emically involved; that is, subjectively involved as insiders in the research process (Jennings, 2010). A number of authors have written about the subjective and human role of the researcher in research processes (see, e.g., Williams, 1990; Harding, 1991; Marcus, 1994; Guba \& Lincoln, 2005; Jennings, 2010). In essence, the early career researchers were self-reporting the lived experiences of the human role and experience in research as noted by those authors.

In the course of questioning their role and the impacts of their decision-making in research processes, the early career researchers provide evidence as well as recognition of their embodied beings being constantly involved in reflexive processes. Seminal works also emphasise the importance of reflexive processes for qualitative research. In particular, the literature notes that reflexivity is more than thinking about one's influence in the field it is also about one's influence in the research design as well as the entire research process. Reflexivity is 'about "ways of seeing which act back on and reflect existing ways of seeing" (Clegg \& Hardy, 1996, p. 4). It involves "metatheoretical reflection that is a form of inquiry in its own right", but also "an applied practice that, while drawing on general metatheoretical categories, is involved integrally ... in the overall process through which research is produced" (Morrow, 1994, p. 228)' (Alvesson \& Sköldberg, 2000, p. 248). 
For the early career researchers, reflexivity was critical for informing decision-making with regard to grounded theory as well as other related qualitative research processes. The subtheme of reflexivity was explicitly linked to the two other essential themes.

Additionally, the three researchers provide evidence of the iterative role and function of axiology (the study of values and ethics) within research processes. Permeating throughout the lived experience narratives were axiological issues, which commenced with the proposition of conducting research through to research process closures. These axiological issues had complementarity with the informing research paradigms being used by each of the researchers. Their axiological questioning reflected associated extant literature regarding axiology (see, e.g., Denzin \& Lincoln, 2005; Guba \& Lincoln, 2005; Jennings 2009; 2010).

\section{Thematically Structuring: Experience of Grounded Theory Learning Contexts and Curricula}

With regard to 'Bildung [(education)] or paideia — the curriculum of being and becoming' (van Manen, 1990, p. 7 ), the three lived experiences emphasised the conditions required to support their learning about and doing grounded theory. Seven supportive conditions were evident as subthemes in the researchers' texts. These included immersion, demonstrations, time for approximation, timely provision of feedback, time and opportunity to practice, clear expectations of learning, models of applied application in real world settings and contexts. These seven conditions match Cambourne's (1984) conditions necessary for conducive learning experiences (refer to Jennings 2000, 2010 for details).

The early career researchers also explicated that research was a corporeal activity in which learning contexts and curricula were socially imbued. In a similar vein, others have written about the need for learning experiences to occur in supportive research cultures. Indeed, a number of authors advocate that it is critical for early career researchers' socialisation and positive learning experiences (Deem \& Brehony, 2000; Offstein, Larson, McNeill \& Mwale, 2004; Conrad, 2006, 2003; Horstmanshof \& Conrad, 2003, Jennings et al., 2009). Moreover, the early career researchers noted that research is not an isolated but rather a social process.

Each of the three researchers moved through similar 'learning' and 'doing' processes. These processes were supported by a set of learning conditions that provided effective scaffolding, which again exhibited similarities to communities of practice (Wenger, 1998) principles. Based on these three researchers' experiences, communities of practice principles had a significant role to play in facilitating Bildung [(education)] or paideia.

\section{Analytically Structuring: Lived Experiences of Early Career Researchers' Engagement With Grounded Theory}

Analytically structuring brings us to theorising the lived experience of learning about and doing grounded theory. Each of the researchers participated in this process. A process, which generated further discourses and refinement of the grounded theory based on their lived experiences. An overview of coding, memoing and interpretations that emerged from the lived experiences as theorising moved into higher order processing and essentialising is presented in Figure 2.

In overview, Figure 2 portrays the raft of experiences that the researchers engaged in during the courses of their research. For the purposes of representation, these experiences are divided into 'learning processes' and 'learning contexts and curricula'. With regard to learning processes these focus on research processes (qualitative and grounded theory) and are labelled 'Research'. Also part of learning processes are the 'Self as researcher' as well as 'Meaning making experiences'. As before, we recognise that this division is arbitrary as research processes, meaning making and the researcher are interconnected. These learning processes are then complemented by the learning contexts and curricula that the researchers experienced. These are presented on the right side of the figure. Where interconnections require emphasis, as is the case with reflexivity and axiology, these are repeated in Figure 2 .

To complement the visual overview the following text provides a narrative framing of the theory. For early career researchers, a number of conditions effectively facilitate and enhance learning processes and engagements associated with learning about and doing grounded theory in order to become a grounded theory researcher. These conditions include immersion, demonstrations, expectations, responsibility, approximation, feedback and practice. These conditions when integrated with communities of practice principles provide the necessary scaffolding to support 'meaning' making processes and development of competencies to enable early career researchers to 'become' and 'belong' to communities of grounded theorists by 'doing' grounded theory. Importantly, the conditions and communities acknowledge and celebrate the intersubjective role of the researcher as learner and the learner as researcher and harness this intersubjectivity through reflective and reflexive processes so that the learner/researcher simultaneously becomes a reflexive practitioner continually conscious of the presence of axiological issues before, during and after the conclusion of any research process.

We have already reflected on the interplay between the three early career researchers' lived experiences and extant literature. Here we briefly reiterate our theorised narrative in relation to the previously mentioned extant literature. Our theory affirms the effectiveness of learning contexts associated with Cambourne's (1984) seven conditions of learning. The significant role of socially contextualised processes can be fulfilled through Wenger's (1998) communities of practice. Our theory also emphasises the role that axiology (Jennings, 2009, 2010) plays in any research paradigm that informs research and notes that axiology is all pervasive in research processes (Guba \& Lincoln, 2005) as is researcher reflexivity (Hertz, 1997). 


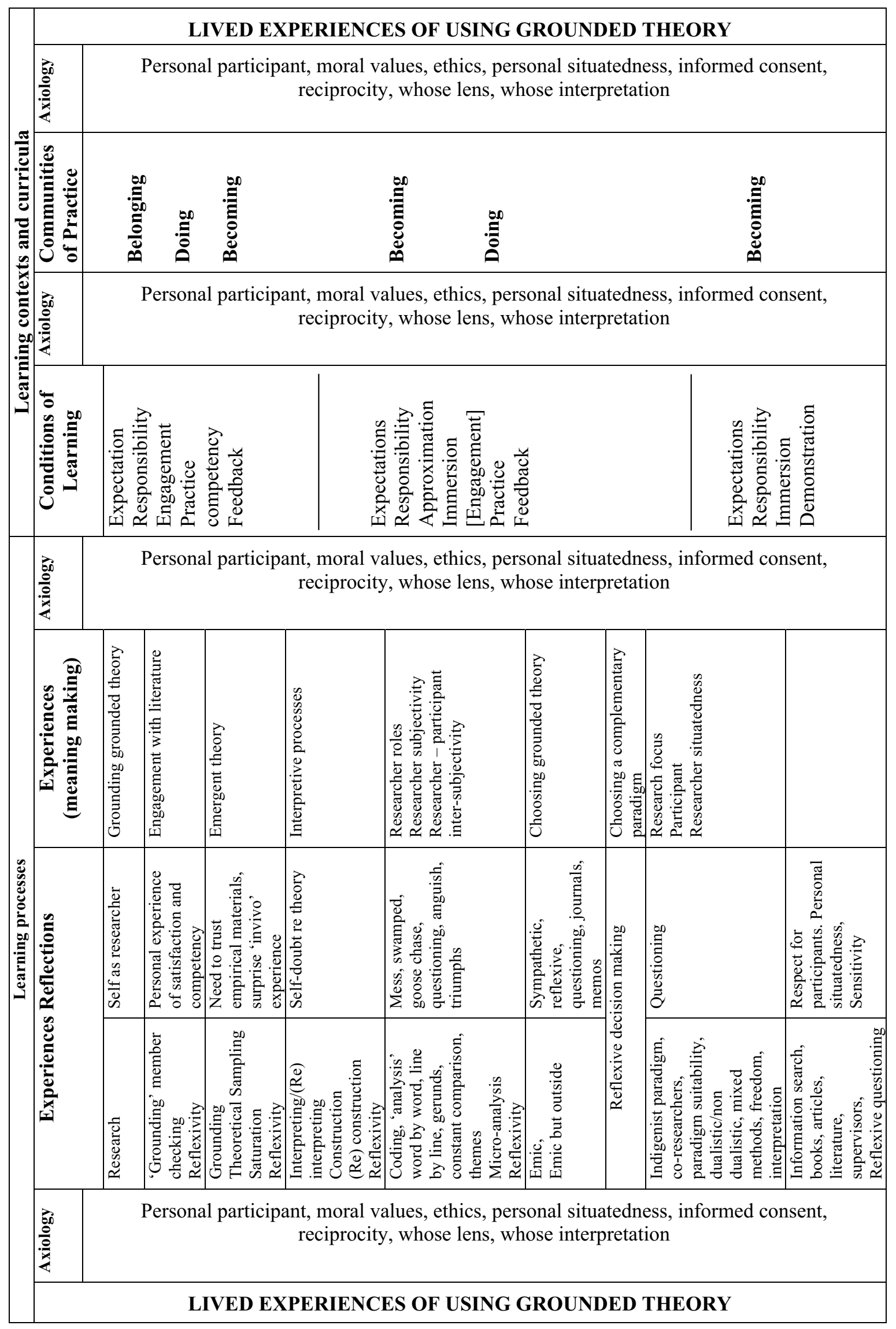




\section{Final Reflections}

At this point, readers will be expecting a conclusion, instead we present final reflections. In doing so, we are mindful of van Manen's (1990, p. 13) commentary: '... it is inappropriate to ask for a conclusion or a summary of a phenomenological study" for the storying itself should be "the thing" - the "incantative, evocative speaking, a primal telling ...' (van Manen, 1990, p. 13). So bearing this in mind, we conclude by revisiting our article's aim.

The article aimed to provide insights into the lived experiences of three early career researchers' learning about and doing grounded theory. In the process, the paper noted seven conditions of learning that were supportive for early career researchers to become grounded theorists. When these conditions are coupled with communities of practice, the early researchers developed axiological and reflexive skill sets. In sharing the lived experiences of learning about and doing grounded theory, the three narratives as well as our grounded theory interpretation of the three narratives provided examples of theory-in-practice.

Finally, the lived experiences of using grounded theory for the three early career researchers underscored the corporeal and affective domain's role in undertaking research. In particular, movement from uncertainty, to competency to the 'joy' of discovery; when a grounded theory emerged from the empirical materials that each of the researchers was using.

\section{References}

Alvesson, M. \& Sköldberg, K. (2000). Reflexive methodology, new vistas for qualitative research. London: Sage.

Arthur, W.S. (1999). What's new? The 1997 Parliamentary Inquiry into Indigenous Business (Centre for Aboriginal Economic Policy Research Discussion Paper, No. 177/1999). Canberra, Australia: The Centre for Aboriginal Economic Policy.

Ateljevic, I., Morgan, N., \& Pritchard. A. (Eds.). (2007). Editors' introduction: Promoting an academy of hope in tourism enquiry. In The critical turn in tourism studies: Innovative research methodologies. Elsevier: Advances in Tourism Research, pp. 1-8.

Australian Institute of Aboriginal and Torres Strait Islander Studies (AIATSIS). (2000). Guidelines for ethical research in Indigenous studies. Canberra, Australia: Commonwealth of Australia. Available at http://www.aiatsis.gov.au/corp/docs/EthicsGuideA4.pdf

Barnacle, R. (2001, December). Phenomenoloyg and education research. Paper presented at AARE conference, Fremantle, Perth, Australia. Available at http://.aare.edu.au/01pap/bar01601.htm

Bender, B., Partlow, C., \& Roth, M. (2008). An examination of strategic drivers impacting U.S. multinational lodging corporations. International fournal of Hospitality E Tourism Administration, 9(3), 219-243.

Berger, P.,L., \& Luckman, T. (1966). The social construction of reality: A treatise in the sociology of knowledge. Harmondsworth, Middlesex: Penguin Books Ltd.

Bourke, E. (1995, September). Dilemmas of integrity and knowledge: Protocol in Aboriginal research. Paper presented at the Indigenous Research Ethics, Townsville, Australia.

Brady, W. (1992). Indigenous control of Aboriginal and Torres Strait Islander research. Paper presented at the Aboriginal Studies Association Conference.

Brady, W. (2001). Indigenous insurgency against the speaking for others. UTS Review, 7(1 May), 1-7.

Cambourne, B. (1984). The origins of teachers' doubts about 'naturalising' literacy education. And some suggestions for easing them. In Reading: 1984 and beyond, selected key papers of the 10th Australian
Reading Conference 1984, (Vol. 2, pp. 17-39). Melbourne, Australia: Australian Reading Association.

Charmaz, K. (1990). Identity dilemmas of chronically ill men. In A. Strauss \& J. Corbin (Eds.), Grounded theory in practice (pp. 35-64). Thousand Oaks, CA.: Sage Publications, Inc.

Charmaz, K. (1994). The Grounded Theory Method. An explication and interpretation. In B.G. Glaser (Ed.), More grounded theory methodology: $A$ reader (pp. 95-115). Mill Valley, CA: Sociology Press.

Charmaz, K. (2000). Grounded theory - Objectivist and constructivist methods. In N.K. Denzin \& Y.S. Lincoln (Eds.), Handbook of qualitative research (2nd ed., pp. 509-535). Thousand Oaks, CA: Sage Publications.

Charmaz, K. (2002). Qualitative interviewing and grounded theory analysis. In J.F. Gubrium \& J.A. Holstein (Eds.), Handbook of interview research: Context and method (pp. 675-694). Thousand Oaks, CA.: Sage Publications.

Charmaz, K. (2003). Qualitative interviewing and grounded theory analysis. In J.A. Holstein \& J.F. Gubrium (Eds.), Inside interviewing: New lenses, new concerns (pp. 311-330). Thousand Oaks, CA: Sage Publications.

Charmaz, K. (2005). Grounded theory in the 21st century: Applications for advancing social justice studies. In N.K. Denzin \& Y.S. Lincoln (Eds.), Handbook of qualitative research (pp. 507-535). Thousand Oaks, CA: Sage.

Charmaz, K. (2006). Constructing grounded theory. A practical guide through qualitative analysis. Thousand Oaks, CA: SAGE Publications.

Coleman, S., \& Crang, M. (2002). Being-on-holiday: Tourist dwelling, bodies and place. Tourist Studies, 3, 47-66.

Connell, J. (1997). International hotel franchise relationships-UK franchisee perspectives. International fournal of Contemporary Hospitality Management, 9(5/6), 215-220.

Connell, J., \& Lowe, A. (1997). Generating grounded theory from qualitative data: The application of inductive methods in tourism and hospitality management research. Progress in Tourism and Hospitality Research, 3(2), 165-173.

Conrad, L. (2003, July). Five ways of enhancing the postgraduate community: student perceptions of effective supervision and support. Proceedings of the HERDSA (Higher Education Research and Development Society of Australasia), Learning for an unknown future: Research and development in higher education. University of Otago. Christchurch, New Zealand.

Conrad, L. (2006). Countering isolation: Joining the research community. In C. Denholm \& T. Evans (Eds.), Doctorates Downunder: Keys to successful doctoral study in Australia and New Zealand((pp. 34-40). Camberwell, Victoria: Australian Council for Educational Research.

Corbin, J., \& Strauss, A. (2008). Basics of qualitative research. (3 ${ }^{\text {rd }}$ ed.). Thousand Oaks, CA: Sage.

Cunningham, P. (2006). Social valuing for Ogasawara as a place and space among ethnic host. Tourism Management, 27(3), 505-516.

Daengbuppha, J. Hemmington, N., \& Wilkes, K. (2004). Using grounded theory approach: theoretical and practical issues in modelling heritage visitor experience. In Smith, K. A. \& C. Schott (Eds.), Proceedings of the New Zealand Tourism and Hospitality Research Conference 2004. Wellington, 8-10 December. p. 64-78.

Decrop, A., \& Snelders, D. (2005). A grounded typology of vacation decision-making. Tourism Management, 26(2), 121-132.

Deem, R., \& Brehony, K. J. (2000). Doctoral students' access to research cultures - are some more unequal than others? Studies in Higher Education, 25(2), 149-165.

Denzin, N.K., \& Lincoln, Y.S. (Eds.). (2000). The discipline and practice of qualitative research. In Handbook of qualitative research (2nd ed., pp. 1-28). Thousand Oaks, CA: Sage Publications.

Denzin, N.K., \& Lincoln, Y.S. (Eds.). (2005). Introduction: The discipline and practice of qualitative research. In Handbook of qualitative research (2nd ed., pp. 1-41). Thousand Oaks, CA.: Sage Publications.

Dilthey, W. (1985). Poetry and experience. Selected Works, Vol V. Princeton, NJ: Princeton University Press. 
Dilthey, W. (1989). Survey of the system of the particular human sciences, in which the necessity of a foundational science is demonstrated. In R.A. Makkreel \& F. Rodi (Eds.), Wilhelm Dilthey selected works Vol. I Introduction to the human sciences. Princeton, NJ: Princeton University Press.

Dodson, M. (2000). Human genetics: Control of research and sharing of benefits. Australian Aboriginal Studies, (1\&2), 56-64.

Dodson, M., \& Smith, D. (2003, March). Indigenous community governance: The key ingredients and principles for sustainable economic development. Paper presented at the Seizing our Economic Future Indigenous Forums: Building a Better Territory, Alice Springs, Australia.

Foley, D. (2000). Indigenous research, differing value systems. The Australian fournal of Indigenous Education, 28(1), 17-30.

Foley, D. (2003). Indigenous epistemology and Indigenous standpoint theory. Social Alternatives, 22(1), 44-52.

Gergon, M.M., \& K.J. Gergen. (2000). Qualitative inquiry: Tensions and transformations. In N.K. Denzin \& Y.S. Lincoln (Eds.), Handbook of qualitative research (2nd ed, pp. 1025-1046). Thousand Oaks, CA.: Sage Publications.

Giddens, A. (1982). Sociology: A brief but critical introduction. London: Macmillan.

Glaser, B.G. (1978). Advances in the methodology of grounded theory. Theoretical sensitivity. Mill Valley, CA: The Sociology Press.

Glaser, B.G. (1992). Emergence vs. forcing: Basics of grounded theory analysis. Mill Valley, CA: Sociology Press.

Glaser, B.G. (Ed). (1994). More grounded theory methodology: A reader. Mill Valley, CA: Sociology Press.

Glaser, B.G. (1998). Doing grounded theory: Issues and discussions. Mill Valley, CA: Sociology Press.

Glaser, B.G. (2001). Conceptualization contrasted with description. Mill Valley, CA: Sociology Press.

Glaser, B.G. (2007). Doing formal grounded theory: A proposal. Mill Valley, CA: Sociology Press.

Glaser, B G., \& Strauss, A. (1967). The discovery of grounded theory: Strategies for qualitative research. Chicago: Aldine Publishing Company.

Goulding, C. (1999). Heritage, nostalgia and the 'grey' consumer. Fournal of Marketing Practice: Applied Marketing Science, 5(608), 177-199.

Goulding, C. (2000). The commodification of the past, postmodern pastiche, and the search for authentic experiences at contemporary heritage attraction. European fournal of Marketing, 34(7), 835-53.

Guba, E.G., \& Lincoln, Y.S. (1994). Competing paradigms in qualitative research. In N.K. Denzin \& Y.S. Lincoln (Eds.), Handbook of qualitative research (pp. 105-117). Thousand Oaks, CA: Sage Publications.

Guba, E.G., \& Lincoln, Y.S. (2005). Paradigmatic controversies, contradictions, and emerging confluences. In N.K. Denzin \& Y.S. Lincoln (Eds.), The Sage handbook of qualitative research (3rd ed., pp. 191-216). Thousand Oaks, CA: Sage.

Gurung, Hum Bahadur. (2008). Fusioning: A grounded theory of participatory governance in the Annapurna conservation Area, Nepal. Unpublished $\mathrm{PhD}$ thesis. Griffith University, Australia.

Hansen, K., Jensen, Ø., \& Gustafsson, I. (2005). The meal experiences of á la carte restaurant customers. Scandinavian fournal of Hospitality $\mathbb{E}$ Tourism, 5(2), 135-151.

Harding, Sandra. (1991). Whose science? Whose knowledge? Milton Keynes: Open University Press.

Hardy, A. (2005). Using grounded theory to explore stakeholder perceptions of tourism. Fournal of Tourism and Cultural Change, 3(2), 108133.

Hillman, W. (2001). Searching for authenticity and experience: Backpackers travelling in Australia. Paper presented at TASA Conference, University of Sydney, Australia.

Hertz, R. (Ed.). (1997). Reflexivity and voice. Thousand Oaks, CA: Sage.

Hobson, J.S.P. (2003). The case for more exploratory and grounded tourism research, Martin Oppermann Memorial Lecture 2001. Pacific Tourism Review, 6(2), 73-81.
Horstmansshof, L., \& Conrad, L. (2003, July). Postgraduate peer support programme: enhancing community. Proceedings of HERDSA (Higher Education Research and Development Society of Australia), Learning for the unknown future: research and development in higher education. University of Otago. Christchurch, New Zealand.

Ivanitz, M. (1999). Culture, ethics and participatory methodology in cross-cultural research. Australian Aboriginal Studies, 2, 46-58.

Jennings, G. R. (1997). The travel experience of cruisers. In M. Oppermann (Ed.), Pacific Rim 2000: Issues, interrelations, inhibitors (pp. 94105). London: CAB International.

Jennings, G.R. (1999). Voyages from the centre to the margins: An ethnography of long term ocean cruisers. Unpublished $\mathrm{PhD}$ thesis, Murdoch University, Australia.

Jennings, G.R. (2000). Educating students to be lifelong learners. Review of Business, 21(4), 58-62.

Jennings, G.R. (2005). Caught in the irons: One of the lived experiences of cruising women. Tourism Research International, 9(2), 177-193.

Jennings, G.R. (2009). Methodologies and methods. In T. Jamal \& M. Robinson (Eds.). Handbook of tourism studies (pp. 672-692). Sage Publications.

Jennings, G. (2010). Tourism research. Brisbane, Australia: John Wiley.

Jennings, G.R., \& Junek, O. (2007). Grounded theory: Innovative methodology or a critical turning from hegemonic methodological praxis in tourism studies? In I. Ateljevic, N. Morgan \& A. Pritchard (Eds.), The critical turn in tourism studies: Innovative research methodologies (pp. 197-210). Elsevier.

Jennings, G.R., Kachel, U., Kensbock, S., \& M-A. Smith. (2009). Tourism and hospitality research student experiences: How to achieve quality, inclusivity and belongingness. Fournal of Hospitality and Tourism Management, 16, 139-147. DOI: 10.1375/ihtm.16.1.139.

Jennings, G., Scantelbury, M., \& Wolfe K. (2009). Tertiary travel and tourism education: Using action research cycles to provide information on pedaggoical applications associated with reflexivity, team-based learning and communities of practice. Fournal of Teaching in Travel and Tourism, 9(3), 193-215.

Jensen, Ø., \& Hansen, K. (2007). Consumer values among restaurant customers. International fournal of Hospitality Management, 26(3), 603622 .

Johns, N., \& Gyimothy, S. (2002). Mythologies of a theme park: An icon of family life. Fournal of Vacation Marketing 8(4): 320-331.

Junek, O. (2004, May). A qualitative inquiry into leisure and travel patterns of international students: Part 1 - background and methodology. The 2nd Asia-Pacific CHRIE (APacCHRIE) Conference $\mathcal{E}$ the 6th Biennial Conference on Tourism in Asia, 2004, Conference Proceedings, Phuket, Thailand.

Kensbock, S. (2007). A grounded theory of tourism entrepreneurs' understanding of sustainable tourism. Unpublished Bachelor of Hotel Management with Honours Dissertation. Gold Coast, Australia: Griffith University.

Kim, H., \& Jamal, T.B. (2007). Tourist quest for existential authenticity. Annals of Tourism Research, 34(1), 181-201.

Kim, Y.G., Eves, A., \& Scarles, C. (2009). Building a model of local food consumption on trips and holidays: A grounded theory approach. International fournal of Hospitality Management, 28(3), 423-431.

Kubacki, K., Skinner, H., Parfitt, S., \& Moss, G. (2007). Comparing nightclub customers' preferences in existing and emerging markets. International fournal of Hospitality Management, 26(4), 957-973.

Kwortnik, R.J. (2003). Clarifying 'fuzzy' hospitality-management problems with depth interviews and qualitative analysis. Cornell Hotel and Restaurant Administration Quarterly.

Lawton, L., \& Weaver, D.B. (2009). Travel agency threats and opportunities: The perspective of successful owners. International fournal of Hospitality \& Tourism Administration, 10, 68-92.

Lim, H.N.J. (2004). Grounded theory approach to travel behaviour research, a methodology to investigate emerging issues. Paper presented at TRAIL Conference, Delft, Netherlands.

Lincoln, Y.S., \& Guba, E G. (2000). Paradigmatic controversies, contradictions and emerging confluences. In N.K. Denzin \& Y.S. Lincoln 
(Eds.), Handbook of qualitative research (2nd ed., pp. 163-188). Thousand Oaks, CA: Sage Publications.

Lynch, P.A. (2005). Sociological impressionism in a hospitality context. Annals of Tourism Research, 32(3), 527-548.

Marcus, G. (1994). What comes (just) after 'Post'? The case of ethnography. In N.K. Denzin \& Y.S. Lincoln (Eds.), Handbook of qualitative research (pp. 563-574). Thousand Oaks: Sage,.

Martin, K. (2003). Ways of knowing, being and doing: A theoretical framework and methods for Indigenous and Indigenist Re-search. Fournal of Australian Studies, Voicing Dissent, 76. Available at http://www.api-network.com/cgi-bin/jas/jas.cgi?issue $=76$

Mattsson, J., \& den Haring, M.J. (1998). Communication dynamics in the service encounter: A linguistic study in a hotel conference department. International fournal of Service Industry Management, 9(5), 416-435.

Mehmetoglu, M., \& Altinay, L. (2006). Examination of grounded theory analysis with an application to hospitality research. International fournal of Hospitality Management, 25(1), 12-33.

Mehmetoglu, M., \& Olsen, K. (2003). Talking authenticity: What kind of experiences do solitary travelers in the Norwegian Lofoten Islands regard as authenticity? Tourism, Culture and Communication, 4(3), 137152.

Moreton-Robinson, A. (2003). Researching whiteness: Some reflections from an Indigenous woman's standpoint. Hecate, 29(2), 72-85.

Nakata, M. (1998). Anthropological texts and Indigenous standpoints. Australian Aboriginal Studies, 2, 3-12.

National Health and Medical Research Council. (2003). Values and ethics: Guidelines for ethical conduct in Aboriginal and Torres Strait Islander health research. Canberra: Commonwealth of Australia.

Oates, W.E. (2003, November-December). Bastards of the bush - Towards an Indigenous Australian research methodology. Paper presented at the International Education Research Conference AARE-NZARE, Auckland, New Zealand.

Offstein, E.H., Larson, M.B., McNeill, A.L., \& Mwale, H.M. (2004). Are we doing enough for today's graduate student? International fournal of Educational Management, 18(7) 396-407.

Presbury, R., Fitzgerald, A., \& Chapman, R. (2005). Impediments to improvements in service quality in luxury hotels. Managing Service Quality, 15(4), 357-373.

Radel, K. (2005, February). Indigenous tourism research: Influences and reflections of epistemological standpoints. Paper presented at the Council for Australian University Tourism and Hospitality Education (CAUTHE) Conference - Sharing Tourism Knowledge, Alice Springs, Australia.

Rigney, L-I. (1996, June). Tools for an indigenist methodology, a Narungga Perspective. Paper presented at The World Indigenous Peoples Education Conference, Albuquerque, New Mexico.

Rigney, L.-I. (1999). Internationalization of an Indigenous anticolonial critique of research methodologies: A guide to Indigenist research methodology and its principles. Fournal for Native American Studies, Wicazo SA Review, 14(2), 109-113.

Rigney, L.-I. (2001a). A first perspective of Indigenous Australian participation in science: Framing Indigenous research towards Indigenous Australian intellectual sovereignty. Retrieved March 4, 2005, from http://www.flinders.edu.au/ yunggorendi/staff/lester/Paper\%20no2\%20lirfirst.pdf.

Rigney, L.-I. (2001b). A first perspective of Indigenous Australian participation in science: Framing Indigenous research towards Indigenous Australian intellectual sovereignty. Kaurna Higher Education fournal, 7,1-13. Available at http://www.flinders .edu.au/yunggorendi/staff/lrigney.php.

Rigney, L.-I. (2003). The first perspective: Culturally safe research practices on or with Indigenous peoples. Paper presented at the 32nd Annual Chacmool Conference - Indigenous people and archaeology: Honoring the past, discussing the present, building for the future, Alberta, Canada.
Riley, R.W. (1995). Prestige-worthy behaviour. Annals of tourism research, 22(3), 630-649.

Riley, R.W. (1996). Revealing socially constructed knowledge through quasi-structured interviews and grounded theory analysis. Fournal of Travel and Tourism Marketing, 15(2), 21-40.

Santos, C.A., \& Buzinde, C. (2007). Politics of identity and space: Representational dynamics. Fournal of Travel Research, 45(3), 322-332.

Scheurich, J.J. (1997). Research methods in the postmodern. London: The Falmer Press.

Schwandt, T.A. (2000). Three epistemological stances for qualitative inquiry: Interpretivism, hermeneutics, and social constructionism. In N.K. Denzzin \& Y.S. Lincoln (Eds.), Handbook of qualitative research (2nd ed., pp. 189-213). Thousand Oaks, CA: Sage.

Silverman, D. (1993). Interpreting qualitative data: Methods for analysing talk, text and interaction. London: Sage Publications.

Soklaridis, S. (2009). The process of conducting qualitative grounded theroy research for a doctoral thesis: Experiences and reflections. The Qualitative Report, 14(4), 719-734.

Smith, L.T. (1999). Decolonizing Methodologies: Research and Indigenous Peoples. London: Zed Books.

Snyder, W., Wenger, E., \& De Sousa Briggs. (2004). Communities of practice in government: Leveraging knowledge for performance. The Public Manager, 32(4), 17-21.

Stanfield II, J.H. (1994). Ethnic modeling in qualitative research. In N.K. Denzin \& Y.S. Lincoln (Eds.), Handbook of qualitative inquiry (pp. 175188). Newbury Park, CA: Sage.

Stevenson, N., Airey, D.W., \& Miller, G. A. (2008). Tourism policy making: The policymakers' perspective. Annals of Tourism Research, 35(3), 732-750.

Strauss, A., \& Corbin, J. (1990). Basics of qualitative research: Grounded theory procedures and techniques. Newbury Park, CA: Sage Publications, Inc.

Strauss, A., \& Corbin, J. (1994). Grounded theory methodology: An overview. In N.K. Denzin \& Y.S. Lincoln (Eds.), Handbook of qualitative research (pp. 273-285). Thousand Oaks, CA: Sage Publications.

Strauss, A., \& Corbin, J. (1998). Basics of qualitative research: Techniques and procedures for developing grounded theory (2nd ed.). Thousand Oaks, CA: Sage Publications.

Testa, M.R. (2007). A deeper look at national culture and leadership in the hospitality industry. International fournal of Hospitality Management, 26(2), 468-484.

Tribe, J. (2007). Critical tourism: rules and resistance. In I. Ateljevic, N. Morgan \& A. Pritchard (Eds.), The critical turn in tourism studies: Innovative research methodologies (pp. 29-39). Elsevier.

van Manen, M. (1990). Researching lived experience: Human Science for an action sensitive pedagogy. London, Ontario, Canada: State University of New York Press.

Vidich, A.J., \& Lyman, S. M. (2000). Qualitative methods: Their history in sociology and anthropology. In N.K. Denzin \& Y.S. Lincoln (Eds.), Handbook of qualitative research (2nd ed.). Thousand Oaks, CA: Sage Publications.

Walsh, K. (2003). Qualitative research: Advancing the science and practice of hospitality. Cornell Hotel and Restaurant Administration Quarterly, 44, 66-74.

Wenger, E. (1998). Communities of practice: Learning, meaning, and identity. Cambridge: Cambridge University Press.

Williams, A. (1990). Reading feminism in fieldnotes. In L. Stanley (Ed.), Feminist praxis (pp. 253-261). London: Routledge.

Woodside, A., MacDonald, R., \& Burford, M. (2004). Grounded theory of leisure travel. Fournal of Travel and Tourism Marketing 17(1), 7-40.

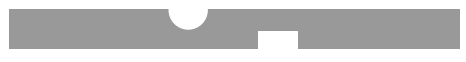

